\title{
Hydro-chemical monitoring of Sakkardara lake at Nagpur (M.S.)
}

\section{B.S. TAPASE}

Article Chronicle : Received: 17.02.2014;

Accepted :

29.05.2015

Key Words : Hydro-chemical parameters,

Sakkardara lake, Hardness, Variation
ABSTRACT : The present paper includes an assessment of the quality of water reservoir situated near Chota Taj Bagh, Sakkardara Square, Nagpur, dist. Nagpur (M.S.). Since 'good' water quality will produce healthier humans than one with poor water quality, an analysis on the hydro-chemical parameters of Sakkardara lake water was made. The lake is situated near Raghuji Nagar in old city area and is beneficial to recreation in present days and fulfill scarcity of water in future. The use of water is mostly for recreation, idol immersion and fishing purpose. The findings of the analysis will prove to be quite informative, to the daily consumers of the water. The water samples were analyzed form June, 2008 to May, 2009. Water samples from this site were analyzed for $\mathrm{pH}$, Conductivity, TDS, Chloride, Alkalinity, Hardness, DO and Sulphate. The results revealed the range of variation in different parameters viz., $\mathrm{pH}$ 8.0 to 8.2 , TDS 789 to $992 \mathrm{mg} / \mathrm{l}$, hardness 210 to $299 \mathrm{mg} / \mathrm{l}$, DO 5.7 to $7.2 \mathrm{mg} / \mathrm{l}$, alkalinity 123 to $148 \mathrm{ppm}$, chloride 136 to $193 \mathrm{mg} / \mathrm{l}$ and sulphate 82 to $130 \mathrm{mg} / \mathrm{l}$. All the hydro-chemical parameters of Sakkardara lake water are within the highest desirable limit or maximum permissible limit set by WHO.

How to CITE THIS ARTICLE : Tapase, B.S. (2015). Hydro-chemical monitoring of Sakkardara lake at Nagpur (M.S.). Asian J. Environ. Sci., 10(1): 107-109. 